\title{
PEMANFAATAN MEDIA SOSIAL DAN PEMENUHAN KEBUTUHAN INFORMASI KETENAGAKERJAAN DI KALANGAN ANGKATAN KERJA MUDA PADA MASA PANDEMI COVID-19
}

\section{THE USE OF SOCIAL MEDIA AND FULFILLED NEEDS OF MANPOWER INFORMATION AMONG YOUNG LABOR FORCE DURING COVID-19 PANDEMIC}

\author{
Parulian Sitompul ${ }^{1}$, Dede Mahmudah ${ }^{2}$, Marudur Pandapotan Damanik ${ }^{3 *}$ \\ 1,2,3 BPSDMP Kominfo Jakarta \\ Jl. Pegangsaan Timur No.19B, Jakarta Pusat \\ paru001@kominfo.go.id,dede002@kominfo.go.id, maru001@kominfo.go.id \\ Diterima tgl. 15/10/2021; Direvisi tgl. 03/12/2021; Disetujui tgl. 15/12/2021
}

\begin{abstract}
Covid-19 pandemic has given enormous effect on global economy and significantly hit manpower sector in Indonesia. Based on some researches, it is shown that young labor force is the most vulnerable group hit by the pandemic. The distribution of manpower information has long been delivered with social media. Therefore, young labor force known as Generation $Z$ is information-technology literate who has actively used social media to update themselves with information about force during this pandemic. Hence, this research aims to identify the relation between the use of social media and the fulfilled needs of manpower information among young labor force, especially during Covid-19 pandemic. With uses and gratification theory (UGT), this research applies quantitative approach to test the proposed hypothesis. With coefficientcorrelation test level Spearman - rho upon the data from 400 respondents, it is shown that the use of social media has a strong relation with the fulfilled needs for information about manpower among young labor force during Covid-19 pandemic. Based on the result, it is hoped that the reliability and the truth of the information will be sustainable so that public can make use of the information and labor force in Indonesia will rise again after being hit by Covid-19.
\end{abstract}

Keywords: Covid-19, UGT, Speraman-rho, Young Labor Force, Manpower, Social Media

\begin{abstract}
ABSTRAK
Pandemi Covid-19 memberikan dampak kepada ekonomi global dan dirasakan khususnya bagi bidang ketenagakerjaan di Indonesia. Dari beberapa penelitian menunjukkan bahwa angkatan kerja muda merupakan kelompok yang paling rentan merasakan dampak tersebut. Penyebaran informasi ketenagakerjaan sejak lama telah banyak dilakukan melalui media sosial. Sehingga angkatan kerja muda sebagai generasi $Z$ yang akrab dengan teknologi informasi, diyakini semakin aktif dalam menggunakan media sosial untuk memenuhi kebutuhan informasi ketenagakerjaan terutama di masa pandemi Covid-19. Oleh karena itu, kajian ini bertujuan untuk mengetahui hubungan antara pemanfaatan media sosial dengan pemenuhan kebutuhan informasi ketenagakerjaan dikalangan angkatan kerja muda, khususnya di masa pandemi Covid-19. Berdasarkanuses and gratification theory (UGT), kajian ini dilakukan melalui pendekatan kuantitatif untuk menguji hipotesis yang diajukan. Melalui uji koefisien korelasi peringkat Spearman - rho terhadap data yang dikumpulkan dari 400 responden, didapatkan hasil bahwa pemanfaatan media sosial memiliki hubungan yang sangat kuat dengan pemenuhan kebutuhan informasi ketenagakerjaan di kalangan angkatan kerja muda pada masa pandemi Covid-19. Berdasarkan hasil tersebut diharapkan informasi ketenagakerjaan yang disebarkan melalui media sosial dapat terus terjaga nilai kebenaran dan kebaruannya, sehingga khalayak dapat memanfaatkan informasi dan pembangunan ketenagakerjaan di Indonesia dapat kembali bangkit setelah dihantam pandemi.
\end{abstract}

Kata kunci: Covid-19, UGT, Speraman-rho, Angkatan Kerja Muda, Ketenagakerjaan, Media Sosial

\section{PENDAhULUAN}

Pandemi Covid-19 yang terjadi sejak awal tahun 2020, mendorong lahirnya berbagai kebijakan yang bertujuan untuk mencegah penularan Covid-19. Hal ini dapat terjadi karena para pemegang kebijakan mendapatkan tekanan untuk dapat merespon kondisi pandemi tersebut. Penyusunan kebijakan pun dilakukan dengan cepat yang bertujuan untuk memperkecil 
kemungkinan meluasnya penyebaran Covid-19. Namun, berbagai kebijakan yang telah ditetapkan seperti menjaga jarak dan melakukan pembatasan pergerakan masyarakat yang diberlakukan di banyak negara, memunculkan argumen bahwa kebijakan sosial semacam itu dapat memicu resesi. Berdasarkan hal tersebut, Ozili \& Arun(2020) menganalisis bahwa wabah Covid-19 memberikan dampak kepada ekonomi global dan memicu resesi global pada tahun 2020, dimana hal tersebut juga dirasakan di Indonesia. Pandemi Covid-19 di Indonesia makin memperburuk kondisi dan jumlah pekerja rentan, yakni pekerja yang kondisi finansialnya tidak menentu dan jauh dari kata "layak" (Bagus P et al., 2020). Berbagai kebijakan terkait pencegahan penularan Covid-19 memberikan dampak di sektor ekonomi, terutama pada keberlangsungan pekerjaan dan perolehan pendapatan bagi para pekerja. Oleh karena itu, tak bisa dipungkiri kondisi pandemi Covid-19 memberikan efek yang besar khususnya bagi pembangunan ketenagakerjaan di Indonesia

Berdasarkan data dari Kementerian Ketenagakerjaan (Kemenaker) menunjukkan bahwa per 31 Juli 2020 sebanyak 2.146.667 pekerja terdampak Covid-19. Dari jumlah tersebut, sebanyak 383.645 orang di-PHK, 1.132 .117 orang dirumahkan; dan 630.905 orang yang bekerja di sektor informal kehilangan pekerjaan atau usahanya mengalami gulung tikar (Nasution, 2020). Pada masa Pembatasan Sosial Berskala Besar (PSBB) di Indonesia, aktivitas ekonomi masyarakat cukup mengalami gangguan. Demikian pula di sektor industri pengolahan, jasa, dan perdagangan, aktivitas terkait proses produksi, distribusi, dan konsumsi banyak yang berhenti dan tersendat. Perusahaan-perusahaan banyak yang memberhentikan dan merumahkan pegawainya tanpa menunaikan hak-hak yang sesuai dengan Undang-Undang (Bagus P et al., 2020). Menurut sebuah studi, pada akhir April 2020 tingkat PHK di Indonesia mencapai 15,6\%. Angka ini terdiri dari 1,8\% PHK dengan pesangon dan 13,8\% PHK tanpa pesangon.Kelompok usia muda yang berkisar antara usia 15 - 24 tahun merupakan kelompok angkatan kerja yang paling berpotensi terkena PHK. Hal ini ditunjukkan dalam penelitian yang dilakukan oleh Ngadi, dkk., dimana kelompok usia 15 - 24 tahun adalah yang paling banyak mengalami PHK bila dibandingkan dengan kelompok usia lainnya, yakni sebanyak 34,5 persen. Potensi besarnya jumlah PHK di kalangan pekerja muda ini telah diprediksi oleh International Labour Organization (ILO) yang memperkirakan sekitar 16\% atau satu dari enam pekerja muda akan kehilangan pekerjaan pada masa pandemi Covid-19(Ngadi et al., 2020).

Untuk menghadapi hal tersebut, pemerintah menyiapkan berbagai cara untuk melindungi para pekerja dari resiko krisis. Diantaranya adalah peningkatan alokasi anggaran penerima Program Keluarga Harapan (PKH), peningkatan nilai dan jumlah penerima Kartu Sembako, peningkatan anggaran Kartu Prakerja, dan pembebasan tarif listrik bagi pelanggan golongan 450 VA dan diskon tarif 50\% untuk pelanggan golongan 900 VA (Bagus P et al., 2020). Namun, usaha - usaha tersebut belum dapat sepenuhnya dirasakan oleh seluruh kelompok pekerja di Indonesia. Melihat bahwa banyak perusahan yang mengurangi lowongan pekerjaan akibat pandemi, setiap orang harus mencari cara untuk bisa bertahan dalam pekerjaannya atau mencari pekerjaan baru agar dapat memenuhi kebutuhan sehari hidup sehari-hari (Nadella \& Rahadi, 2020).

Survei Angkatan Kerja Nasional (Sakernas) yang dilakukan oleh Badan Pusat Statistik (BPS) pada bulan Februari 2021 menunjukkan bahwa jumlah angkatan kerja di Indonesia mencapai 139,81 juta orang. Dari jumlah tersebut sebanyak 8,75 juta orang masuk dalam kategori pengangguran dan 11,42 juta orang setengah pengangguran. Dari sisi pendidikan, tingkat pengangguran dengan latar belakang pendidikan menengah atau SMA/sederajat merupakan persentase yang tertinggi, yakni $9,72 \%$. Dalam survei tersebut juga menyoroti tentang tingginya Tingkat Pengangguran Terbuka (TPT) di Kelompok Umur Muda yakni sebanyak 18,03\%. Dari persentase tersebut dimaknai bahwa dari 100 orang penduduk dengan usia 15 - 24 tahun yang masuk dalam kategori angkatan kerja, ada 18 orang yang tidak bekerja. Dari survei tersebut juga 
diketahui bahwa share Penganggur Umur Muda bila dibandingkan dengan total penganggur mencapai 43,70\%(BPS, 2021a). Kondisi tersebut menjadi hal yang sangat mungkin terjadi, sebab saat terjadi pandemi perusahaan banyak yang mengalami kebangkrutan dan tidak banyak perusahaan yang membuka lowongan pekerjaan. Kesempatan untuk menjadi pegawai baru di saat pandemi menjadi hal yang sulit. Oleh karena itu, para pencari kerja termasuk angkatan kerja muda yang berstatus fresh graduateharus benar-benar berusaha dalam mendapatkan informasi mengenai kesempatan kerja di masa pandemi seperti saat ini.

Pesatnya perkembangan teknologi informasi memberikan peluang bagi penyebaran informasi yang lebih cepat dengan lingkup yang sangat luas. Oleh karena itu, di Indonesia terus digalakkan pembangunan masyarakat informasi seiring dengan meningkatnya teknologi informasi dan keterbukaan informasi publik. Kehidupan masyarakat informasi digambarkan dalam sebuah kondisi dimana semua lapisan masyarakat bebas untuk mengakses berbagai sumber informasi. Masyarakat informasi juga sadar akan pentingnya informasi dalam menjalani aktivitas sehari-hari, serta terbukanya wawasan dan pandangan dalam pemanfaatan teknologi, diringi dengan meratanya perkembangan lembaga-lembaga yang mengelola perpustakaan, dokumentasi dan informasi. Pada masyarakat informasi kemajuan SDM dapat terjadi, serta meningkatnya pemanfaatan informasi dan hal-hal teknis yang memanfaatkan ilmu pengetahuan dan teknologi (IPTEK). Informasi juga dikelola secara baik, disampaikan tepat pada waktunya serta dibungkus dengan apik melalui teknologi dan berkembang menjadi komoditi bernilai ekonomis(Harahap \& Adeni, 2020). Penetrasi internet yang semakin meningkat dan menjadi media utama yang sering digunakan untuk menyebarkan informasi dan komunikasi, mencerminkan bahwa Indonesia memiliki ciri-ciri masyarakat informasi. Peningkatan penetrasi di Indonesia ditunjukkan dalam gambar 1 dimana berdasarkan Survei Asosiasi Penyelenggara Jasa Internet Indonesia (APJII) periode 2019 - 2020 (Q2) diketahui bahwa penetrasi pengguna internet di Indonesia sebesar 73,7\%. Hal ini meningkat bila dibandingkan dengan penetrasi pengguna internet di Indonesia pada tahun 2018 yakni sebesar 64,8\% (APJII, 2020).

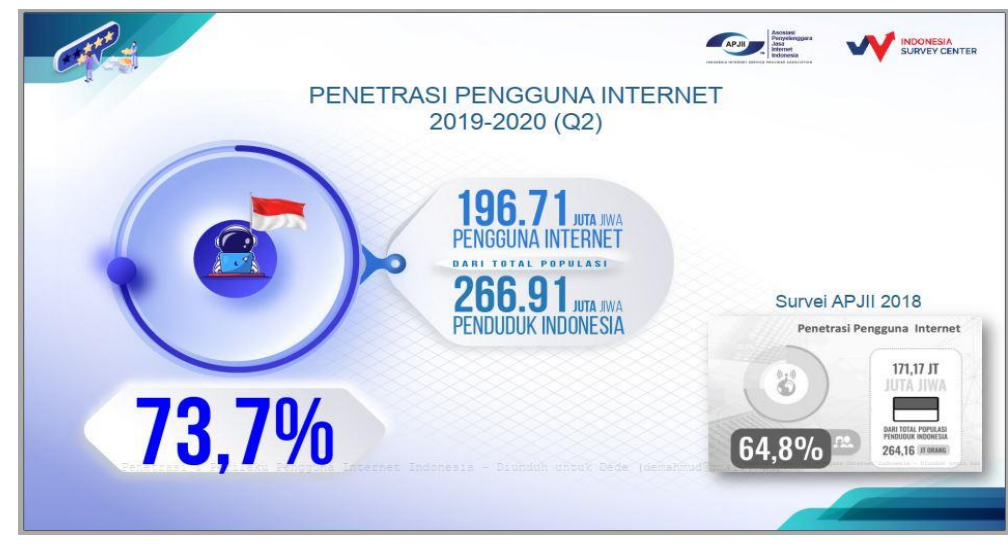

Sumber: Laporan Survei Internet APJII 2019 - 2020 (Q2)

Gambar 1.Penetrasi Pengguna Internet di Indonesia Tahun 2019-2020 (Q2)

Survei yang dilakukan APJII juga menghimpun data kepada responden untuk menyebutkan dan mengurutkan alasan yang mendorong responden untuk menggunakan internet. Dari hasil olah datanya menunjukkan bahwa sebanyak 51,5\% menyebutkan bahwa mengakses media sosial adalah alasan utama mereka untuk menggunakan internet. Terkait dengan media sosial yang sering digunakan diantaranya adalah Facebook sebanyak 65,8\%, YouTube sebanyak 61\%, Instagram sebanyak $42,3 \%$, Whatsapp sebanyak $31,1 \%$, Twitter sebanyak $10 \%$, Line sebanyak $2,5 \%$ dan 
LinkedIn sebanyak 2,1\%. Media sosial seperti TikTok, Telegram, Facebook Messenger, dan media sosial lainnya juga diketahui digunakan oleh responden, namun jumlahnya dibawah $2 \%$ (APJII, 2020). Dari berbagai uraian diatas menjabarkan bahwa pandemi Covid-19 membuat pergerakan masyarakat menjadi semakin terbatas, sehingga media sosial pun semakin sering digunakan oleh masyarakat untuk memenuhi segala kebutuhannya. Media sosial saat ini juga semakin beragam, dimana Cahyono menyebutkan bahwa Media sosial adalah suatu media daring, yang membuat para pengguna tidak kesulitan untuk ikut berkolaborasi , berpartisipasi, berinteraksi, berbagi, berdiskusi, dan membuat konten dengan semua jenis media sosial(Novianti et al., 2020). Media sosial seperti Facebook, WhatsApp, WeChat, YouTube, Line, Instagram, LinkedIndan Google plus, mengubah cara komunikasi melalui fitur dan layanan yang inovatif. Sebagian besar situs jejaring sosial ini menawarkan kepada pengguna kesempatan untuk mempresentasikan masing-masing individu dan menghubungkan mereka dengan pengguna jejaring sosial lain yang sudah ada maupun yang baru(Hossain, 2019).

Kietzmann, Hermkens, McCarthy, dan Silvestre (Rosini \& Nurningsih, 2018)menjelaskan 7 fungsi media sosial yang berkontribusi untuk memahami mengenai mekanisme sebuah media sosial, yaitu:

1. Identitas, dimana hal ini menggambarkan tentang cara seseorang mengungkapkan diri pribadi di media sosial.

2. Percakapan, mengenai cara, motivasi, frekuensi, dan isi komunikasi.

3. Kehadiran, hal ini ditentukan oleh bentuk media. Dimana komunikasi dapat bersifat interpersonal dengan diskusi tatap muka misalnya atau dimediasi seperti percakapan melalui panggilan suara. Dengan kedekatan media, seseorang dapat membedakan antara komunikasi asinkron misalnya melalui e-mail dengan komunikasi sinkron yang dilakukan melalui obrolan langsung.

4. Kelompok, berupa komunitas atau sub-komunitas yang menjadi unsur media sosial. Dalam media sosial terdapat dua jenis grup utama, yaitu kelompok yang terbuka untuk publik (public group), dan grup yang tertutup (private group).

5. Hubungan, menjelaskan hubungan antar anggota dalam sebuah komunitas. Hubungan tersebut menentukan "apa dan bagaimana proses pertukaran informasiantar anggota ".

6. Reputasi, adalah ukuran yang diberikan publik untuk mengidentifikasi diri mereka sendiri, terutama yang berkaitan dengan orang lain di masyarakat. Ada beberapa hal yang terkait dengan hal ini yakni kekuatan, sentimen, semangat, dan jangkauan.

7. Berbagi, berkaitan tentang proses pertukaran informasi diantara pengguna media sosial. Ada dua implikasi yang mendasar mengenai hal ini, pertama, objek yang dibagikan dan kedua, kecenderungan mereka untuk berbagi.

Media sosial memudahkan masing-masing individu untuk saling bernteraksi dengan tidak ada batas jarak, waktu, maupun biaya. Para pengguna juga menjadi mudah berbagi informasi, saling melakikan komunikasi, mendapatkan hiburan dan hal-hal lain yang dapat ditemui di media sosial. Di masa pandemi Covid-19, media sosial digunakan juga untuk memenuhi kebutuhan informasi terkait ketenagakerjaan. Hal tersebut juga dimanfaatkan oleh Kemenker dalam menyebarkan informasi ketenagakerjaan. Langkah yang dilakukan oleh Kemenaker diantaranya melakukan pengembangandan perluasan akses terhadap informasi serta melakukan edukasi khususnya di bidang ketenagakerjaan. Penggunaan situs dan media sosial pada masing-masing instansi terus dioptimalkan. Informasi seperti peraturan ketenagakerjaan, pasar kerja, pelatihan kerja, pemagangan dan konten edukasi bidang ketenagakerjaan seperti pengawasan, hubungan industrial, dan lain lain, harus mudah didapatkan dan diakses oleh masyarakat. Informasi dan edukasi yang 
terkait dengan bidang ketenagakerjaan baik dari Kemenaker, Dinas Tenaga Kerja (Disnaker), maupun Balai Latihan Kerja (BLK) akan disebarluaskan melalui media sosial. Hal ini diharapkan bisa menjadi rujukan masyarakat dalam mengakses informasi ketenagakerjaan karena langsung dikeluarkan oleh sumber terpercaya (Ratya, 2018). Oleh karena itu, segala informasi terkait ketenagakerjaan dapat dengan mudah disebarkan melalui media sosial, baik media sosial resmi milik instansi pemerintah maupun dari berbagai lapisan masyarakat, dimana mereka dapat dengan mudah menyebarkan berbagai informasi melalui media sosial yang mereka miliki.

Teori yang digunakan dalam melakukan menjelaskan perilaku pengguna dalam memanfaatkan suatu media adalah Uses and Gratification Theory (UGT). Teori ini mengungkapkan bahwa sebenarnya pengguna media sesungguhnya tidak pasif, dan tidak hanya menerima begitu saja apa yang disajikan oleh media. Para pengguna secara aktif menentukan sendiri media, fitur, serta informasi apa saja yang akan mereka gunakan (uses). Kemudian setelah penggunaan tersebut, mereka memiliki harapan untuk mendapatkan sesuatu (gratification)sebagai hasil dari aktivitas penggunaan media tersebut (Grissa, dalam (Muttaqin, 2019)). Menurut Katz dkk. dalam Karunia H et al.(2021)) terdapat tiga asumsi yang digunakan dalam UGT. Asumsi pertama, pengguna dihadapi oleh banyak pilihan media yang dapat digunakan. Berbagai macam pilihan media tersebut muncul sebagai upaya untuk memenuhi kebutuhan pengguna akan informasi dariaspek psikologis dan sosial. Kedua, dari berbagai macam kebutuhan pengguna dimana pemanfatan media mengidentifikasi kebutuhan dari masing-masing pengguna. Asumsi yang ketiga menjelaskan bahwaadanya persaingan antar media untuk memenuhi kebutuhan informasi para penggunanya. Suparmo(2017) memaparkan bahwa UGT merupakan teori sosiologi mengenai penggunaan media massa oleh khalayak, berupa teks maupun gambar yang berbunyi maupun bergerak berisi tulisan atau audio visual yang disiarkan. Dalam perkembangan media saat ini sering kali disebut dengan istilah posting, share dan forward. Khalayak melakukan hal tersebut untuk mendapatkan keuntungan berupa kepuasan. Dalam perkembangan saat ini, media tidak lagi hanya diartikan sebagai media massa konvensional, karena media sudah didominasi dalam bentuk media digital yang dapat dioperasikan berjuta manusia secara individual, yang umum disebut sebagai media sosial. Rohmah(2020) juga memaparkan bahwa UGT digunakan dalam penelitian terkait pemanfaatan berbagai media baru, diantaranya adalah penggunaan smartphone, internet, media sosial, microblogging, pesan instan, permainan daring, berita beranimasi, serta media hiburan.

McQuail (dalam(Karunia $\mathrm{H}$ et al., 2021)) menjelaskanada 4 (empat) faktor yang menjadi alasan khalayak menggunakan media sosial, diantaranya adalah sebagai media sebagai hiburan, untuk mendapatkan informasi, dan memperkuat identitas pribadi mereka melalui penambahan wawasan, dan untuk menciptakan hubungan yang bersifat personal serta melakukan interaksi sosial dengan orang lain. Pada akhirnya media sosial berpengaruh untuk membuat khalayak memiliki hubungan dengan pihak lain. Griffin (dalam (Karunia H et al., 2021)) menjelaskan terdapat beberapa kelompok-kelompok yang menggambarkan tujuan pengguna dalam memanfaatkan media berdasarkan UGT, yakni:

1. Passing time, yaitu untuk mengisi waktu luang

2. Companionship, yaitu upaya untuk menapatkan teman baru

3. Escape, yaitu sebuah upaya untuk mengisi waktu agar dapat terlepas dari suatu masalah

4. Enjoyment, yaitu upaya untuk memperoleh kesenangan pribadi

5. Social Interaction, untuk menciptakan hubungan sosial dengan orang lain

6. Relaxation, yaitu upaya agar diri sendiri menjadi lebih santai dan rileks

7. Information, ditujukan untuk memperoleh informasi

8. Excitement, yaitu upaya untuk menyenangkan diri sendiri 
Kajian yang menganalisis media sosial yang didasarkan pada UGT telah dilakukan oleh beberapa pihak. Salah satunya kajian yang dilakukan oleh Rohmah(2020) mengenai manfaat mediasosial pada di masa pandemi Covid-19 serta bagaimana media sosial mampu memenuhi kebutuhan informasi masyarakat. Kajian tersebut dianalisis menggunakan UGT dan dari hasil analisis serta uji statistik menunjukkan bahwa sebanyak $80 \%$ responden setuju bahwa media sosial bermanfaat sebagai sosial informasi, $93 \%$ responden media sosial memanfaatkan sebagai media informasi Covid 19, 83\% setuju bahwa informasi di media sosial dapat membantu sesama pengguna, $80 \%$ orang menyetujui bahwa media sosial mampu memuaskan sebagai pelarian dari rutinitas dan masalah pribadi di masa Covid-19, 85\%menyetujui media sosial dapat memuaskan dalam pencarian informasi Covid-19 dan 92\%menyetujui bahwa informasi di media sosial memuaskan untuk melakukan sesuatu. Whiting \& Williams(2013) juga melakukan kajian yang diberi tajuk, "Why people use social media: a uses and gratifications approach". Kajian ini bertujuan untuk menggambarkan pentingnya UGT dalam penggunaan media sosial. Melalui studi eksplorasi, dilakukan wawancara mendalam dengan 25 informan yang menggunakan media sosial. Dari kajian ini mengidentifikasi 10 kegunaan dan kepuasan khalayak dalam menggunakan media sosial, yakni interaksi sosial (88\%), pencarian informasi (80\%), waktu luang (76\%), hiburan (64\%), relaksasi (60\%), untuk saling terhubung (56\%), untuk saling mengekspresikan opini (56\%), kenyamanan (52\%), berbagi informasi (40\%), dan pengawasan (20\%).

Dari kajian tersebut menunjukkan bahwa salah satu hal yang sering dilakukan oleh khalayak saat menggunakan media sosial adalah untuk melakukan pencarian informasi. Hal ini dipahami karena pencarian informasi merupakan aktivitas setiap orang, sedangkan yang membedakannya hanyalah jenis informasi yang dibutuhkan. Adapun kebutuhan informasi dibagi menjadi beberapa jenis, yang pertama yaitu kebutuhan fisiologis dimana kebutuhan informasi dirasa sangat penting seperti kebutuhan primer. Kedua adalah kebutuhan afektif,yaitu keinginan untuk mencari kesenangan saat mencari informasi yang dibutuhkan. Ketiga adalah kebutuhan kognitif, yaitu kebutuhan untuk mendapatkan pengetahuan dan pembelajaran (Fatmawati, 2015). Katz, dkk (dalam Nurul \& Zalmi(2017)) juga memaparkan bahwa teori kebutuhan yang harus dipuaskan dalam rangka pengembangan diri dapat diuraikan seperti berikut ini :

1. Kebutuhan kognitif yang berkaitan dengan kebutuhan untuk memperkuat pengetahuan dan

2. pemahaman orang terhadap lingkungannya. Kebutuhan ini juga dapat memberikan kepuasan atas hasrat keinginan dan penyelidikan individu.

3. Kebutuhan afektif yang dikaitkan dengan kebutuhan estetis, hal yang dapat menyenangkan dan pengalaman-pengalaman emosional. Afeksi dalam hal ini bermakna sebagai penghargaan diri terhadap situasi, kondisi, waktu, lingkungan, dan juga orang lain.

4. Kebutuhan integrasi personal yakni terkait dengan penguatan kredibilitas, kepercayaan,stabilitas, dan status individu. Kebutuhan-kebutuhan ini berasal dari hasrat seseoranguntuk mencari harga diri.

5. Kebutuhan integrasi sosial yang dikaitkan dengan kebutuhan untuk berkomunikasi dengankeluarga, teman, dan orang lain dalam bermasyarakat. Kebutuhan ini didasari olehkeinginan individu untuk berkomunikasi dengan seseorang atau dengan kelompoklain.

6. Kebutuhan berkhayal dimana kebutuhan ini dikaitkan dengan kebutuhan untuk melarikan diri, melepaskan ketegangan, dan hasrat untuk mencari hiburan.

Penelitian yang membahas tentang pemanfaatan media sosial khususnya untuk memenuhi kebutuhan informasi yang menggunakan UGT juga telah banyak dilakukan. Diantaranya kajian yang dilakukan oleh Ashrianto \& Yustitia(2020). Mereka melakukan penelitian tentang pemanfaatan media sosial untuk mencari informasi terkait Papua. Berdasarkan temuan dari 
penelitian tersebut, diketahui bahwa motivasi dan pengalaman pengguna media sosial merupakan hal yang penting dalam penggunaan media sosial untuk mencari informasi tentang Papua, dimana hal tersebut sesuai dengan asumsi dasar dari UGT. Khalayak sekarang diyakini sangat aktif dalam memilih media yang mereka digunakan, dan diarahkan pada tujuan yang sesuai dengan harapan mereka.Dari hasil perhitungan diperoleh hasil yang menunjukkan bahwa hipotesis terkait perilaku penggunaan media sosial berpengaruh positif terhadap kepedulian Mahasiswa UPN "Veteran" Yogyakarta tentang isu Papua bisa diterima. Dalam kajian ini juga mengacu pada perilaku penggunaan media sosial dipahami secara kualitatif. Berdasarkan hal tersebut, penelitian ini menyimpulkan bahwa sosial media tidak bisa dijadikan satu-satunya media untuk mencari informasi tentang Papua. Penggunaan media yang bervariasi terjadi karena maraknya berita bohong, dimana menunjukkan adanya literasi media dari responden yang menyadari bahwa tidak ada satu saluran tertentu yang mampu memuaskan semua kebutuhan audiens dan adanya kemauan audiens untuk mencari informasi dari sumber yang lain.Kajian lainnya dilakukan oleh Nia \& Loisa(2019) yang bertujuan untuk meneliti bagaimana penggunaan media sosial Facebook terhadap pemenuhan kebutuhan informasi serta alasan penggunaan media sosial Facebook bagi ibu rumah tangga. Studi menggunakanpendekatan mix-method yaitu gabungan kuantitatif dan kualitatif, dan menggunakan metode studi kasus. Studi ini mengkonfirmasi bahwa penggunaan media sosial Facebook berpengaruh pada aktivitas pemenuhan kebutuhan informasi di kalangan ibu rumah tangga.

Dari berbagai paparan tersebut menunjukkan bahwa pemenuhan kebutuhan informasi menjadi alasan bagi masyarakat untuk menggunakan media sosial. Kegiatan penyebaran dan pencarian informasi melalui media sosial menjadi hal yang sudah umum dilakukan oleh masyarakat. Di masa pandemi Covid-19 yang mendorong terjadinya resesi ekonomi, PHK, kebankrutan, dan terbatasnya kesempatan kerja yang dibuka, membuat penggunaan media sosial untuk memenuhi kebutuhan informasi terkait ketenagakerjaan menjadi tak dapat dihindari lagi, khususnya oleh para angkatan kerja yang masuk dalam Kelompok Umur Muda yang rentan terkena dampak dari pandemi ini. Angkatan kerja Kelompok Umur Muda berusia 15 sampai 24 tahun, dimana rentang usia tersebut masuk dalam kategori generasi $\mathrm{Z}$ atau disebut juga generasi internet (iGeneration). Generasi tersebut lahir pada kisaran tahun 1995 - 2010 dan merupakan generasi paling muda yang memasuki angkatan kerja. Generasi $\mathrm{Z}$ mampu mengaplikasikan semua kegiatan dalam satu waktu misalnya menggunakanmedia sosial dengan telepon selular, sambil melakukan pencarian informasi menggunakan komputer portabel, dan sembari mendengarkan musik menggunakan penyuara telinga (earphone). Berbagai kegiatan yang dilakukan kebanyakan berhubungan dengan dunia maya, karena sejak kecil generasi ini sudah mengenal teknologi dan akrab menggunakangawai (Putra, 2017). Dengan karakteristik tersebut, angkatan kerja muda pun menjadi generasi yang menyelesaikan segala permasalahannya dengan penggunaan teknologi informasi, khususnya saat kesempatan kerja di masa pandemic Covid-19 ini semakin sulit didapatkan. Sehingga sangat mungkin terjadi angkatan kerja muda tersebut menggunakan kemampuannya dibidang teknologi informasi untuk mencari informasi terkait ketenagakerjaan melalui media sosial. Oleh karena itu, kajian ini mencoba untuk mengetahui tentang hubungan antara pemanfaatan media sosial dengan pemenuhan kebutuhan informasi terkait ketenagakerjaan di kalangan angkatan kerja muda pada masa pandemi Covid-19. Dari kajian ini diharapkan dapat memberikan gambaran tentang pemanfaatan media sosial di kalangan angkatan kerja muda dalam memenuhi kebutuhan informasi ketenagakerjaan di masa pandemi ini. Sehingga dapat memberikan masukan bagi para pemegang kebijakan dalam merancang kembali pembangunan ketenagakerjaan di Indonesia setelah dihantam oleh pandemi Covid-19. 
Berbagai kajian mengenai pemanfaatan media sosial untuk memenuhi kebutuhan informasi memang telah banyak dilakukan. Namun, kajian ini mencoba untuk secara khusus mengangkat pemanfaatan media sosial dalam pemenuhan kebutuhan informasi ketenagakerjaan di masa pandemi Covid-19 dari sisi angkatan kerja muda. Generasi yang diduga paling rentan terkena dampak bidang ketenagakerjaan di masa pandemi, sekaligus sebagai generasi internet yang memiliki kemampuan lebih dalam pemanfaatan teknologi informasi dibandingkan dengan generasigenerasi sebelumnya. Aktifnya generasi $\mathrm{Z}$ dalam menggunakan media, sejalan dengan asumsi dari UGT yang dijadikan landasan dalam kajian ini, bahwa pengguna aktif menentukan sendiri media, fitur, serta informasi apa saja yang akan digunakan dan memiliki harapan untuk mendapatkan hasil dari aktivitas penggunaan media sosial tersebut. Sehingga diduga terdapat hubungan antara pemanfaatan media sosial dengan pemenuhan kebutuhan informasi terkait ketenagakerjaan di kalangan angkatan kerja muda pada masa pandemi Covid-1, yang secara sederhana digambarkan dalam kerangka konsep berikut ini :

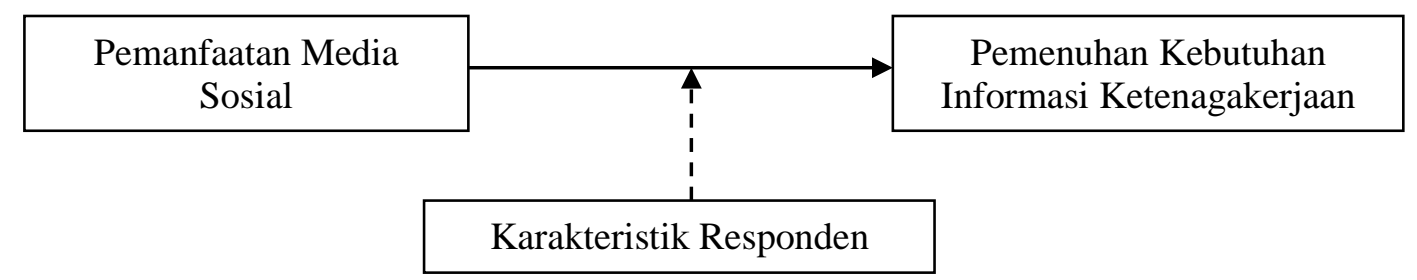

Gambar 2. Kerangka Konsep Penelitian

Hipotesis penelitian ini dirumuskan sebagai berikut:

Ho : Tidak terdapat hubungan antara pemanfaatan media sosial denganpemenuhan kebutuhan informasi ketenagakerjaan di kalangan angkatan kerja muda pada masa pandemi Covid19

Ha: Terdapat hubungan antara pemanfaatan media sosial denganpemenuhan kebutuhan informasi ketenagakerjaan di kalangan angkatan kerja muda pada masa pandemi Covid19

\section{METODE PENELITIAN}

Jenis penelitian ini merupakan studi deskriptif kuantitatif sesuai dengan tujuan penelitianuntuk mengetahui hubungan antara pemanfaatan media sosial dengan pemenuhan kebutuhan informasi ketenagakerjaan di kalangan angkatan kerja muda pada masa Pandemi Covid19. Menurut Kriyantono,penelitian deskriptif berhubungan dengan frekuensi, jumlah, dan karakteristik dari fenomena yang diteliti. Oleh sebab itu, studi deskriptif mempunyai berbagai tujuan antara lain : membuat secara sistematis, faktual, dan akurat tentang fakta-fakta dan sifat-sifat populasi atau objek tertentu(Saleh \& Pitriani, 2018). Variabel bebas dalam penelitian ini adalah pemanfaatan media sosial,sedangkan variabel terikatadalah pemenuhan kebutuhan informasi ketenagakerjaan. Instrumen pengukuran menggunakan skala Likert untuk mengukur sikap, pendapat dan persepsi responden terkait fenomena sosial. Melalui skala Likert, maka variabel yang akan diukur dijabarkan menjadi indikator variabel. Kemudian indikator tersebut dijadikan sebagai titik tolak untuk menyusun item-item instrumen yang dapat berupa pernyataan (Sugiyono, dalam (Saleh \& Pitriani, 2018)). Dalam Tabel 1 berikut ini dipaparkan mengenai masing-masing variabel:

Tabel 1.Variabel Penelitian

\begin{tabular}{lc}
\hline \multicolumn{1}{c}{ Variabel Teoritis } & Variabel Operasional \\
\hline Variabel Bebas $(\mathbf{X})$ & Pemanfaatan Media Sosial : \\
\hline
\end{tabular}




\begin{tabular}{ll}
\hline Pemanfaatan Media Sosial & - Informasi \\
& - Identitas diri \\
& - Integrasi dan interaksi sosial \\
& - Hiburan \\
\hline Variabel Terikat (Y) & Pemenuhan Kebutuhan Informasi Ketenagakerjaan : \\
Pemenuhan Kebutuhan & - Kognitif \\
Informasi Ketenagakerjaan & - Afektif \\
& - Integrasi personal \\
& - Integrasi sosial \\
& - Kebutuhan berkhayal (pelepasan) \\
\hline
\end{tabular}

Berdasarkan data dari katalog Keadaan Angkatan Kerja di Indonesia pada Semester 1 tahun 2021 (BPS, 2021b) diketahui bahwa Jumlah angkatan kerja muda di Indonesia yang masuk dalam kelompok usia 15 - 24 tahun berjumlah 17.374 .302 orang. Perhitungan sampel dilakukan menggunakan rumus Slovin, dengan populasi (N) sebanyak 17.374.302 orang dan margin of error (e) sebesar 5\% atau 0,05. Maka perhitungan sampelnya adalah sebagai berikut :

$$
\begin{aligned}
& \mathrm{n}=\mathrm{N} /\left(1+\left({\left.\left.\mathrm{N} x \mathrm{e}^{2}\right)\right)}_{\mathrm{n}}=17.374 .302 /\left(1+\left(17.374 .302 \times 0,05^{2}\right)\right)\right.\right. \\
& \mathrm{n}=17.374 .302 /(1+(17.374 .302 \times 0,0025)) \\
& \mathrm{n}=17.374 .302 /(1+43.435,755) \\
& \mathrm{n}=1000 / 43.436,755 \\
& \mathrm{n}=399,99(\text { dibulatkan }) \\
& \mathrm{n}=400 \text { orang }
\end{aligned}
$$

Penelitian ini menggunakan teknik sampling non-probability, dimana pemilihan sampel tidak dilakukan secara acak. Teknik sampling initidak memberikan peluang yang sama kepada semua populasi sebagai sampel, sehingga kesimpulan akhir hanya terbatas pada sampel yang terlibat dan tidak dapat merepresentasikan keseluruhan populasi(Budiastuti \& Bandur, 2020). Pengambilan sampel dilakukan secara purposif karena terdapat karakteristik yang khusus untuk tujuan analisis data. Dalam penelitian ini sampel ditentukan sesuai dengan tujuan penelitian yaitu angkatan kerja muda yang berusia 15 - 24 tahun serta memiliki akun media sosial.Pengumpulan data dilaksanakan melalui penyebaran kuesioner yang berisi pertanyaan-pertanyaan terkait dengan media sosial dan pemenuhan kebutuhan informasi ketenagakerjaan yang disebar kepada 400 responden yang mengikuti kegiatan sertifikasi Vocational School Graduate Academy (VSGA), yang diselenggarakan oleh Balai Pengembangan Sumber daya Manusia dan Penelitian Komunikasi dan Informatika (BPSDMP Kominfo) Jakarta. Kegiatan tersebut merupakan pelatihan bagi angkatan kerja muda untuk mendapatkan sertifikat kompetensi berbasis Standar Kompetensi Kerja Nasional Indonesia (SKKNI), khususnya yang terkait dengan bidang Taknologi Informasi dan Komunikasi (TIK). Kegiatan VSGA tersebut dilaksanakan bertahap dari bulan Mei 2021 sampai dengan bulan September 2021.

Analisis data diawali dengan uji validitas dan uji reliabilitas. Uji validitas bertujuan untuk memastikan butir-butir pernyataan sesuai dengan variabel yang hendak diukur. Sedangkan uji reliabilitas instrumen bertujuan untuk mengukur seberapa konsisten instrumen penelitian untuk mengukur dalam waktu yang berbeda (Budiastuti \& Bandur, 2020). Instrumen penelitian dinyatakan valid apabila koefisien korelasi antara skor itemdan skor totalnya dalam taraf signifikansi 0,05 dengan rumus Korelasi Product Moment Pearson, atau mempunyai nilai r hitung> $r$ tabel (Saleh \& Pitriani, 2018).Terkait dengan uji reliabilitas, (Budiastuti \& Bandur, 2020) memaparkan bahwa tes konsistensi internal adalah Alpha's Cronbach. Kategori nilai koefisien alpha dapat dijelaskan sebagai berikut: 
$>0 \quad=$ Tidak memiliki reliabilitas (no reliability)

$>>0.70=$ Reliabilitas yang dapat diterima (acceptable reliability);

$>>0.80=$ Reliabilitas yang baik (good reliability); dan

$>>0.90=$ Reliabilitas yang sangat baik (excellent reliability)

$>1=$ Reliabilitas sempurna (perfect reliability)

Setelah uji validitas dan reliabilitas, analisis data dilanjutkan dengan melakukan pengolahan data secara deskriptif dan inferensial. Statistika deskriptif dimaksudkan untuk mendeskripsikan karakteristik data tanpa melakukan generalisasi atau penarikan kesimpulan(Husnul et al., 2019).

Selanjutnya studi ini juga menggunakan metode analisis korelasi Spearman-rho untuk menentukan kekuatan hubungan antar kedua variabel. Analisis korelasi Spearman digunakan karena hasil uji normalitas Kolmogorov-Smirnov melebihi $\alpha=0,05$ yang menyatakan bahwa data tidak berdistribusi normal. Kesimpulan hasil uji korelasi kemudian akan dinyatakan sebagai berikut

- Jika Ho memiliki nilai signifikan $<0,05$, terdapat korelasi yang signifikanyang artinya data menunjukkan ada hubungan antara pemanfaatan media sosial dengan pemenuhankebutuhan informasi ketenagakerjaan di kalangan angkatan kerja muda pada masa pandemi Covid-19.

- Jika Ho memiliki signifikan >0,05 maka tidak terdapat korelasi yangsignifikan, yang artinya tidak terdapat hubungan antara pemanfaatan media sosial dengan pemenuhan kebutuhan informasi ketenagakerjaan di kalangan angkatan kerja muda pada masa pandemi Covid-19.

Untuk menginterpretasikan tingkat hubungan berdasarkan koefisien korelasi yang diperoleh, digunakan pedoman sebagai berikut ini(Suharto, 2015):

$$
\begin{aligned}
& 0,00-1,99 \text { Sangat Rendah } \\
& 0,20-0,399 \text { Rendah } \\
& 0,40-0,599 \text { Sedang } \\
& 0,60-0,799 \text { Kuat } \\
& 0,80-1,000 \text { Sangat Kuat }
\end{aligned}
$$

\section{HASIL DAN PEMBAHASAN}

Kementerian Komunikasi dan Informatika (Kemkominfo) sejak tahun 2018 melaksanakan program Digital Talent Scholarship (DTS) yakni program pelatihan pengembangan kompetensi yang diberikan kepada talenta digital Indonesia. Program DTS tahun 2021 didesain untuk menciptakan ekosistem seimbang dalam memaksimalkan peran pentahelix (pemerintah, komunitas/masyarakat, institusi pendidikan tinggi, dunia usaha, dan media) untuk menjadi fasilitator dan akselerator pendukung ekonomi digital. Program DTS bertujuan untuk meningkatkan keterampilan dan daya saing, produktivitas, profesionalisme sumber daya manusia bidang TIK bagi angkatan kerja muda Indonesia, masyarakat umum, dan aparatur sipil negara. Salah satu akademi dari program DTS ini adalah VSGA yang merupakan program pelatihan dan sertifikasi nasional untuk para lulusan SMK/sederajat serta Diploma 3 dan 4 yang belum bekerja dan memiliki latar belakang pendidikan sesuai dengan skema pelatihan masing-masing. Pelatihan diberikan secara intensif oleh instruktur yang berpengalaman, sedangkan sertifikasi dilakukan oleh Lembaga Sertifikasi Profesi (LSP) yang telah memiliki lisensi dari Badan Nasional Sertifikasi Profesi (BNSP). Program VSGA ini diselenggarakan secara luring maupun secara daring (https://digitalent.kominfo.go.id/pelatihan/VSGA).

Penyelenggaraan Bimbingan Teknis secara luring dilaksanakan oleh 8 Unit Pelaksana Teknis Badan Penelitian dan Pengembangan Sumber Daya Manusia Kementerian Komunikasi dan Informatika (UPT Balitbang SDM Kominfo). Sedangkan Pelatihan Intensif dan Sertifikasi yang 
dilakukan secara Daring dilaksanakan oleh Perguruan Tinggi yang telah bekerja sama dengan Badan Penelitian dan Pengembangan Sumber Daya Manusia Kementerian Komunikasi dan Informatika. Oleh karena itu, BPSDMP Kominfo Jakarta sebagai salah satu UPT Balitbang SDM Kominfo kemudian mendapatkan tugas untuk menyelenggarakan program VSGA tersebut. Pelaksanaan program tersebut diharapkan dapat meningkatkan kompetensi lulusan Pendidikan Vokasi yang akan berdampak dalam upaya pengurangan angka pengangguran serta mampu memenuhi kebutuhan tenaga terampil di bidang teknologi di Indonesia. Oleh karena itu, penelitian ini melakukan pengumpulan data dari para peserta proram VSGA tersebut, karena peserta kegiatan tersebut memiliki kriteria yang sesuai dengan tujuan dari kajian ini, dimana para peserta merupakan angkatan kerja muda dan diyakini memiliki akun media sosial. BPSDMP Kominfo Jakarta menyelenggarakan program VSGA di Kota Jakarta, Kota Jambi, Kota Palembang, Kota Pangkalpinang, Kabupaten Banyuasin, Kabupaten Bangka, dan Kabupaten Belitung.

\subsection{Hasil Uji Validitas dan Reliabilitas}

Data yang diperoleh dari responden yang telah mengisi kuesioner, kemudian dilakukan pengujian validitas, instrumen diuji dengan menghitung koefisien korelasi antara skor itemdan skor totalnya dalam taraf signifikansi 0,05 dengan rumus Korelasi Product Moment Pearsondengan menggunakan aplikasi SPSS. Instrumen bisa dikatakan valid jika mempunyai nilai $r$ hitung $>r$ tabel. Jumlah responden dalam pengujian instrumen ini sebanyak 50 orang, sehingga nilai $r$ tabel didapatkan adalah $\mathrm{df}=\mathrm{n}-2(50-2)=48$, maka tabel $\mathrm{r}$ pada angka 48 dan signifikasi $5 \%$ adalah 0,284 .

Tabel 2. Hasil Uji Validitas Variabel Penelitian

\begin{tabular}{ccccc}
\hline Variabel Penelitian & Item & $\begin{array}{c}\mathbf{r} \\
\text { hitung }\end{array}$ & $\begin{array}{c}\mathbf{r} \text { tabel taraf } \\
\mathbf{0 , 0 5} \mathbf{n}=\mathbf{4 8}\end{array}$ & Status \\
\hline Pemanfaatan Media Sosial (X) & X1 & 0,709 & 0,284 & Valid \\
& X2 & 0,903 & 0,284 & Valid \\
& X3 & 0,750 & 0,284 & Valid \\
& X4 & 0,665 & 0,284 & Valid \\
& X5 & 0,829 & 0,284 & Valid \\
& X6 & 0,812 & 0,284 & Valid \\
Pemenuhan Kebutuhan Informasi & X7 & 0,810 & 0,284 & Valid \\
Ketenagakerjaan (Y) & X8 & 0,866 & 0,284 & Valid \\
& Y1 & 0,767 & 0,284 & Valid \\
& Y2 & 0,907 & 0,284 & Valid \\
& Y3 & 0,859 & 0,284 & Valid \\
& Y4 & 0,887 & 0,284 & Valid \\
& Y5 & 0,803 & 0,284 & Valid \\
& Y6 & 0,850 & 0,284 & Valid \\
& Y7 & 0,646 & 0,284 & Valid \\
& Y8 & 0,783 & 0,284 & Valid \\
\hline
\end{tabular}

Sumber : Hasil Olah Data Penelitian (2021)

Dalam tabel 2 dipaparkan mengenai hasil pengujian validitas untuk variabel penelitian, yakni variabel pemanfaatan media sosial (X) dan variabel pemenuhan kebutuhan informasi ketenagakerjaan (Y). Dari tabel tersebut ditampilkannilai $\mathrm{r}$ hitung dari masing-masing item pernyataan, dimana nilai tersebut menjadi nilai korelasi yang akan dibandingkan dengan $r$ tabel. Sehingga berdasarkan data yang ditampilkan dalam tabel 2 tersebut, tterlihat bahwa semua item 
pernyataan dari masing-masing variabel nilai $r$ hitungnya lebih besar dari nilai $r$ tabel. Dengan demikian semua item pernyataan dari kedua variabel tersebut dinyatakan valid.

Tabel 3. Hasil Uji Reliabilitas Variabel Penelitian

\begin{tabular}{ccc}
\hline $\begin{array}{c}\text { Variabel } \\
\text { Penelitian }\end{array}$ & $\begin{array}{c}\text { Nilai } \\
\text { Cronbach's } \\
\text { Alpha }\end{array}$ & Keterangan \\
\hline $\begin{array}{c}\text { Pemanfaatan } \\
\text { Media Sosial (X) } \\
\text { Pemenuhan } \\
\text { Kebutuhan } \\
\text { Informasi }\end{array}$ & 0,915 & Reliabel \\
Ketenagakerjaan & 0,925 & Reliabel \\
(Y) & & \\
\hline & & \\
\hline
\end{tabular}

Sumber : Hasil Olah Data Penelitian (2021)

Uji Reliabilitas berguna untuk menunjukan konsistensi hasil pengukuran bila dilakukan pengukuran kembali terhadap objek yang sama. Pengukuran reliabilitas dilakukan dengan menggunakan Cronbach's Alpha. Dari tabel 3 menunjukkan hasil dari perhitungan uji reliabilitas dari masing-masing variabel, dimana kedua variabel tersebut mendapatkan nilai Cronbach's Alpha lebih dari 0,90 , sehingga instrumen tersebut dinyatakan reliabel dengan reliabilitas yang sangat baik (excellent reliability).

\subsection{Karakteristik Responden}

Dalam bagian ini dipaparkan mengenai hasil pengolahan data secara deskriptif, khususnya terkait karakteristik responden. Terkait dengan jenis kelamin dari responden, sebanyak $62 \%$ berjenis kelamin laki-laki, dan sebanyak $38 \%$ orang berjenis kelamin perempuan. Karakteristik responden bila dilihat dari sisi usia, ditunjukkan dalam gambar 3.

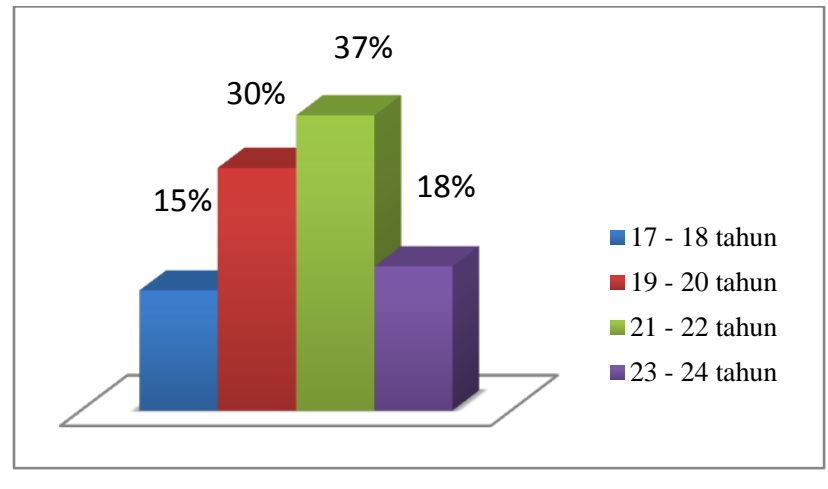

Sumber : Hasil Olah Data Penelitian (2021)

Gambar 3. Karakteristik Berdasarkan Usia Responden

Dari Gambar 3 tersebut menunjukkan bahwa responden paling banyak berada di kisaran usia 21 - 22 tahun yakni sebanyak 37\%. Responden yang berusia $19-20$ tahun sebanyak $30 \%$ dan yang berusia $23-24$ tahun sebanyak $18 \%$. Sedangkan kisaran usia responden yang paling sedikit adalah 17 - 18 tahun yakni sebanyak 15\%. Karakteritsik responden dari penelitian ini juga dilihat dari sisi status pekerjaan responden saat ini, sepertinya yang digambarkan dalam Gambar 4. 


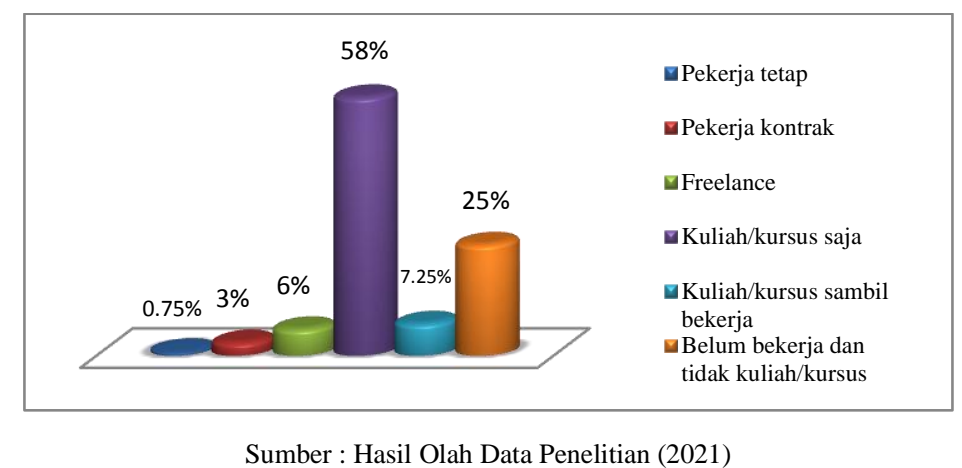

Gambar 4. Karakteristik Berdasarkan Status Pekerjaan Responden

Dari gambar 4 tersebut terlihat bahwa sebagian besar responden, yakni sebanyak 58\% kegiatan sehari-harinya berstatus sebagai mahasiswa, karena mereka hanya kuliah/kursus saja. Dari semua responden terdapat $25 \%$ yang menyebutkan saat ini statusnya belum bekerja dan juga tidak kuliah/kursus. Hanya $0,75 \%$ responden yang mengatakan sudah berstatus sebagai pekerja tetap. Di lain sisi, terdapat responden yang sedang kuliah/kursus sambil bekerja, yakni sebanyak 7,25\% . Responden juga ada yang berstatus sebagai pekerja kontrak sebanyak 6\% dan freelance sebanyak $3 \%$. Karakteristik responden berdasarkan lokasi tempat mereka mengikuti VSGA secara luring ditunjukkan dalam gambar 5.

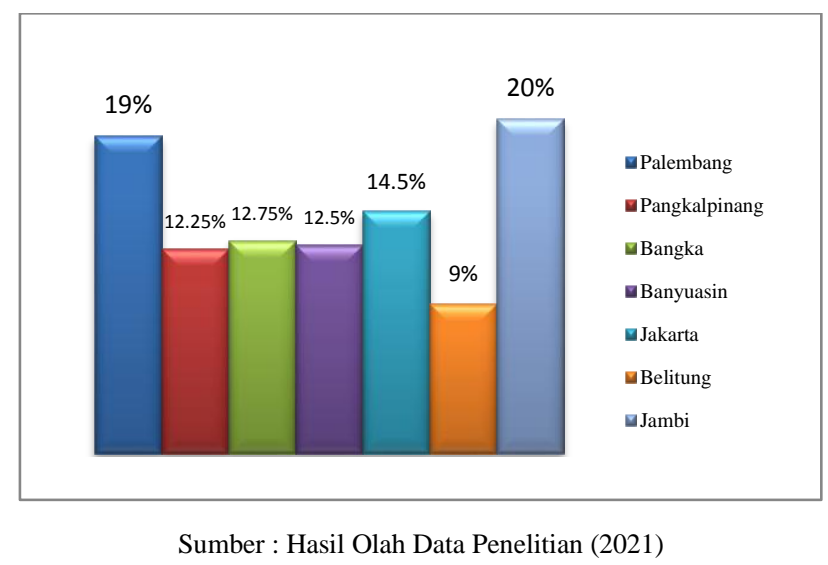

Gambar 5. Karakteristik Berdasarkan Lokasi Responden Mengikuti VSGA Secara Luring

Kota Jambi menjadi kota yang terbanyak menjadi lokasi responden dalam mengikuti VSGA secara luring yakni sebanyak 20\%. Jumlah responden yang mengikuti kegiatan VSGA secara luring di Kota Palembang juga tidak jauh berbeda yakni 19\%. Hal ini dimungkinkan karena kedua kota tersebut memang sudah direncanakan oleh BPSDMP Kominfo Jakarta untuk menampung peserta VSGA yang lebih banyak bila dibandingkan dengan kota-kota lainnya. Lokasi yang paling sedikit menjadi tempat responden dalam mengikuti VSGA secara luring adalah Kabupaten Belitung yakni sebanyak 9\%. Hal ini jugadimungkinkan karena Kabupaten Belitung memang sudah direncanakan oleh BPSDMP Kominfo Jakarta untuk menampung peserta VSGA yang paling sedikit bila dibandingkan dengan kota-kota lainnya. Sedangkan untuk kota/kabupaten lainnya, jumlahnya tidak jauh berbeda yakni di Kota Jakarta sebanyak 14,5\%, Kabupaten Bangka sebanyak 12,75\%, Kabupaten Banyuasin sebanyak 12,5\%, dan Kota Pangkalpinang sebanyak 12,25\%. Karakteristik responden berdasarkan media sosial yang paling sering diakses ditunjukkan dalam gambar 6 . 


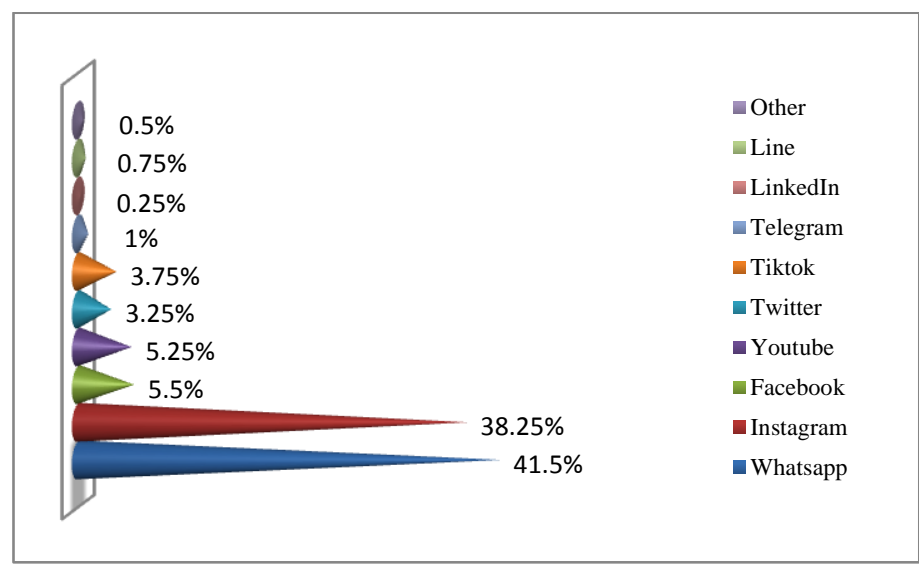

Sumber : Hasil Olah Data Penelitian (2021)

Gambar 6. Karakteristik Berdasarkan Media Sosial yang Paling Sering Diakses oleh Responden

Terkait dengan media sosial yang paling sering diakses oleh responden maka Whatsapp adalah yang paling banyak disebutkan oleh responden sebagai media sosial yang paling sering mereka akses, yakni sebanyak 41,5\%. Media sosial selanjutnya yang paling sering diakses oleh responden adalah Instagram yang disebutkan oleh 38,25\% responden. Facebook disebutkan oleh 5,5\% responden sebagai media sosial yang paling sering diakses. Sebanyak 5,25\% responden menyebutkan mereka paling sering mengakses Youtube. Sedangkan sisanya yakni 3,75\% menyebutkan paling sering mengakses TikTok, 3,25\% paling sering mengakses Twitter, dan $1 \%$ paling sering mengakses telegram. Sedangkan Line dan LinkedIn masing-masing paling sering diakses oleh $0,75 \%$ dan $0,25 \%$ responden. Kajian ini juga menunjukkan karakteristik responden berdasarkan durasi waktu mereka dalam sehari untuk mengakses medias sosial, hal ini ditampilkan dalam gambar 7.

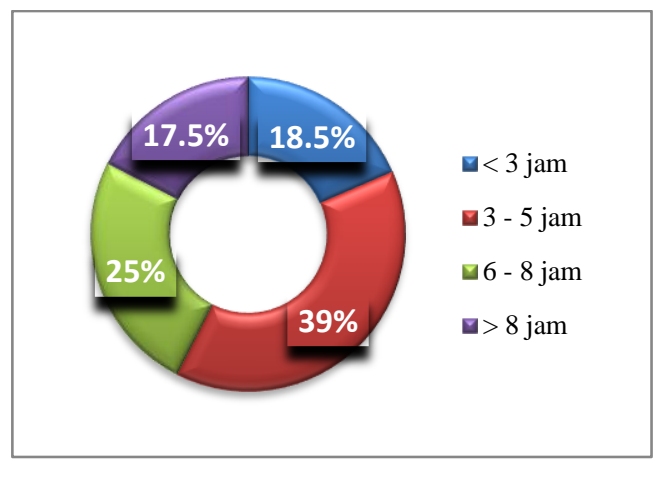

Sumber : Hasil Olah Data Penelitian (2021)

Gambar 7. Karakteristik Berdasarkan Durasi Waktu Dalam Sehari Untuk Mengakses Media Sosial

Dari gambar 7 tersebut terlihat bahwa responden paling banyak mengakses media sosial selama 3 - 5 jam dalam sehari, yakni 39\% responden. Sebanyak 25\% responden menyebutkan bahwa mereka mengakses media sosial selama $6-8$ jam sehari. Terdapat $18,5 \%$ responden yang memberikan informasi bahwa mereka mengakses media sosial selama kurang dari 3 jam dalam sehari. Sedangkan sisanya sebanyak $17,5 \%$ menyatakan bahwa dalam sehari dapat mengakses media sosial selama lebih dari 8 jam. Kemudian dalam penelitian ini ditanyakan juga mengenai intensitas responden untuk mengakses informasi mengenai ketenagakerjaan melalui media sosial. Data mengenai hal tersebut ditampilkan dalam gambar 8. 


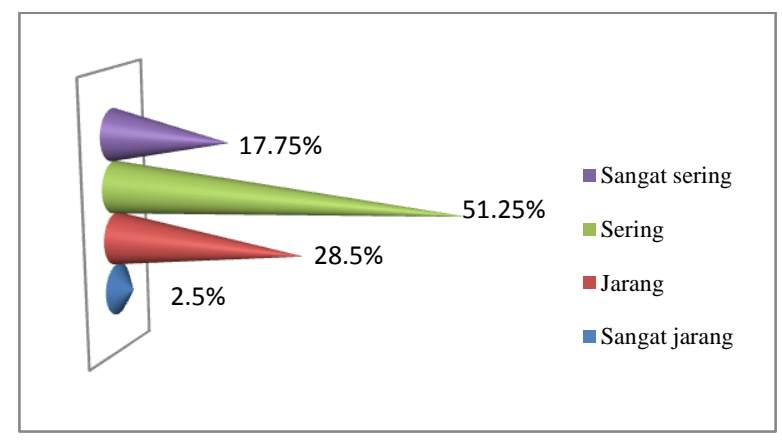

Sumber : Hasil Olah Data Penelitian (2021)

Gambar 8. Karakteristik Berdasarkan Intensitas Mengakses Informasi Mengenai Ketenagakerjaan Melalui Media Sosial

Dalam Gambar 8 tersebut menunjukkan bahwa sebagian besar responden sering mengakses media sosial untuk mencari informasi mengenai bidang ketenagakerjaan, yakni sebanyak 51,5\% responden. $28,5 \%$ responden diantaranya menyatakan jarang menggunakan media sosial untuk mengakses informasi ketenagakerjaan. Terdapat $17.75 \%$ responden yang menyebutkan sangat sering menggunakan media sosial untuk mengakses informasi ketenagakerjaan. Namun, dari 2,5\% responden menyebutkan bahwa mereka sangat jarang mengakses informasi mengenai ketenagakerjaan melalui media sosial. Karakteristik terakhir yang menggambarkan tentang responden penelitian ini adalah terkait informasi ketenagakerjaan yang paling sering dicari oleh responden, seperti yang dipaparkan dalam gambar 9.

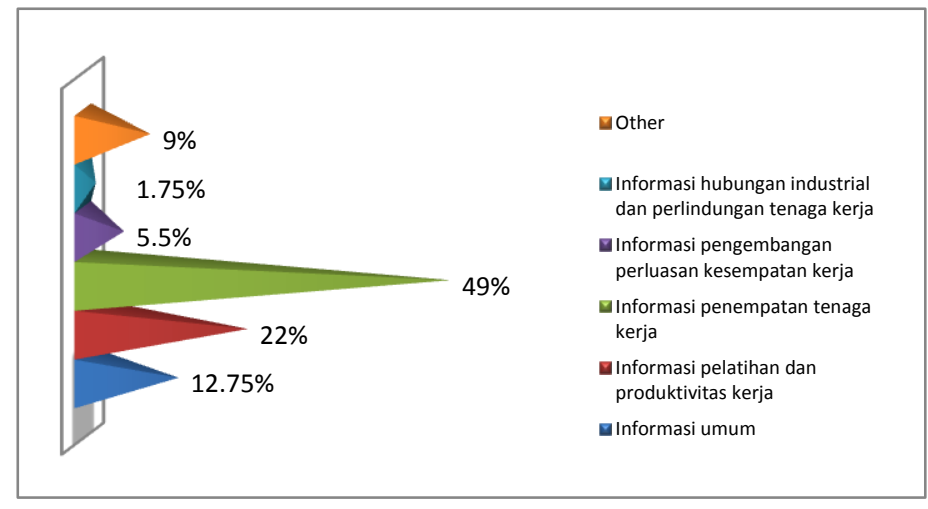

Sumber : Hasil Olah Data Penelitian (2021)

Gambar 9. Karakteristik Berdasarkan Informasi Mengenai Ketenagakerjaan yang Paling Sering Dicari

Jenis informasi yang paling banyak disebutkan oleh responden sebagai informasi ketenagakerjaan yang paling sering dicari adalah informasi mengenai penempatan kerja, seperti kesempatan kerja atau lowongan pekerjaan, dimana $49 \%$ responden menyebutkan hal tersebut. Kemudian 22\% responden menyebutkan bahwa mereka paling sering mencari informasi ketenagakerjaan terkait dengan pelatihan dan produktivitas kerja. Informasi umum dibidang ketenagakerjaan seperti jumlah pengangguran atau jumlah angkatan kerja oleh 12,75\% responden menjadi informasi ketenagakerjaan yang paling sering dicari. 5,5\% responden paling sering mencari informasi tentang pengembangan peluasan kesempatan kerja, misalnya informasi mengenai peluang usaha yang dapat dilakukan. Sebanyak 1,75\% menyebutkan paling sering mencari informasi terkait hubungan industrial dan perlindungan tenaga kerja. Sedangkan sisanya mengakses informasi lainnya, yakni sebanyak $9 \%$. 


\subsection{Uji Hipotesis}

Sebelum melakukan uji hipotesis, data terlebih dahulu diolah untuk mengetahui normalitasnya. Uji normalitas dilakukan dengan metode Kolmogorov-Smirnov dan Shapiro-Wilk menggunaman aplikasi SPSS. Hasil uji normalitas disajikan seperti pada Tabel 4 dibawah ini.

Tabel 4. Hasil Uji Normalitas Variabel Penelitian

\begin{tabular}{lcccccc}
\hline Variabel Penelitian & \multicolumn{3}{c}{ Kolmogorov-Smirnov } & \multicolumn{3}{c}{ Shapiro-Wilk } \\
\cline { 2 - 7 } & Statistic & df & Sig. & Statistic & df & Sig. \\
Pemanfaatan Media & 0.227 & 400 & 0.000 & 0.906 & 400 & 0.000 \\
Sosial & & & & & & \\
$\begin{array}{l}\text { Pemenuhan } \\
\text { Kebutuhan }\end{array}$ & 0.247 & 400 & 0.000 & 0.876 & 400 & 0.000 \\
Informasi & & & & & & \\
Ketenagakerjaan & & & & & & \\
\hline & a. Lilliefors Significance Correction & & \\
& Sumber : Hasil Olah Data Penelitian (2021)
\end{tabular}

Dari Tabel 4 diperoleh hasil uji normalitas dari variabel-variabel dalam penelitian dimana nilai signifikansi (p) pada hasil uji Kolmogorov-Smirnov kurang dari $\alpha=0,05$. Hasil ini menunjukkan bahwa data tidak berdistribusi normal, sehingga uji hipotesis dilakukan menggunakan statistik non parametrik yaitu analisis korelasi Spearman-rho.

Tabel 5. Hasil Uji Hipotesis Variabel Penelitian

\begin{tabular}{|c|c|c|c|c|}
\hline & & & $\begin{array}{l}\text { Pemanfaatan } \\
\text { Media Sosial }\end{array}$ & $\begin{array}{c}\text { Pemenuhan } \\
\text { Kebutuhan } \\
\text { Informasi } \\
\text { Ketenagakerjaan }\end{array}$ \\
\hline \multirow{8}{*}{$\begin{array}{l}\text { Spearman's } \\
\text { rho }\end{array}$} & \multirow[t]{4}{*}{ Pemanfaatan Media Sosial } & Correlation & 1.000 & $0.825^{* *}$ \\
\hline & & Coefficient & & \\
\hline & & $\begin{array}{l}\text { Sig. } \\
\text { tailed })\end{array}$ & . & 0.000 \\
\hline & & $\mathrm{N}$ & 400 & 400 \\
\hline & \multirow{4}{*}{$\begin{array}{c}\text { Pemenuhan Kebutuhan } \\
\text { Informasi Ketenagakerjaan }\end{array}$} & Correlation & $0.825^{* *}$ & 1.000 \\
\hline & & Coefficient & & \\
\hline & & $\begin{array}{l}\text { Sig. } \\
\text { tailed })\end{array}$ & 0.000 & . \\
\hline & & $\mathrm{N}$ & 400 & 400 \\
\hline
\end{tabular}

Berdasarkan uji hipotesis yang ditunjukkan pada tabel 5, diperoleh hasil koefisien korelasi (rho)sebesar 0,825 dengan signifikansi (sig.2-tailed) $=0,000$. Dari hasil ini dapatdisimpulkan bahwa terdapat hubungan yang signifikan antara pemanfaatan media sosial dengan pemenuhan kebutuhan informasi ketenagakerjaan di kalangan angkatan kerja muda pada masa pandemi Covid- 
19. Nilai koefisien Spearman (rho) sebesar 0,825 atau berada diantara angka $0,80-1,00$ menunjukkan bahwa terdapat hubungan yang sangat kuat, sehingga dapat disimpulkanbahwa hipotesis penelitian ini diterima dan memiliki hubungan antar variabel signifikan.

\subsection{Diskusi}

UGT adalah teori yang berfokus pada penggunaan (uses) media, dimana penggunanya mengharap untuk mendapatkan kepuasan (gratification) sehingga dapat memenuhi kebutuhannya. Teori ini menganggap khalayak sebagai individu yang aktif dan selektif, serta memiliki tujuan tertentu saat menggunakan media. Dengan kata lain, khalayak memiliki preferensi tersendirisaat menerima dan memproses pesan yang diberikan media. Oleh karena itu, saat memutuskan untuk menerima informasi, pengguna memiliki motif yang menjadi dasar khalayak untuk memilih menggunakan media tersebut. Begitu pula dengan angkatan kerja muda yang dari kisaran usia masuk dalam generasi z, generasi yang dianggap sudah sangat akrab dengan teknologi informasi. Sehingga mereka secara aktif memutuskan akan menggunakan media sosial apa dan dengan tujuan apa. Dari kajian ini diperoleh informasi bahwa 39\% responden bisa menghabiskan waktu selama 3 sampai 5 jam sehari untuk mengakses media sosial. Bahkan terdapat 17,5\% yang menyatakan menghabiskan waktu lebih dari 8 jam sehari untuk mengakses media sosial. Generasi Z yang menjadi angakatan kerja termuda bila dibandingkan generasi lainnya, tentu telah memiliki perhatian yang lebih terdapat informasi ketenagakerjaan. Hal ini terlihat dari 51,25\% responden menyatakan sering menggunakan media sosial untuk mencari informasi mengenai ketenagakerjaan. Responden pun telah selektif melakukan jenis informasi yang dibutuhkan, dimana 49\% responden menyebutkan paling sering mencari informasi mengenai penempatan kerja. Selain itu 22\% responden fokus mencari informasi mengenai pelatihan dan produktivitas kerja. Dengan kata lain, responden dalam kajian ini menggunakan media sosial didasarkan pada alasan tertentu, yakni untuk memenuhi kebutuhan informasi terkait ketenagakerjaan. Hal ini tidak jauh berbeda dengan hasil penelitian yang dilakukan (Nia \& Loisa, 2019), dimana responden penelitian yang merupakan ibu rumah tangga memiliki tujuan awal ketika memanfaatkan media sosial Facebook yaitu untuk memenuhi kebutuhan informasinya.

Uji hipotesis megnhasilkan nilai koefisien korelasi spearman-rho sebesar 0,825. Angka ini menunjukkan adanya korelasi yang kuat variabel pemanfaatan media sosial dengan pemenuhan kebutuhan informasi ketenagakerjaan. Tanda bintang $(* *)$ menunjukkan bahwa hubungan bernilai signifikan pada angka signifikasi sebesar 0,01. Angka koefisien korelasi tersebut juga bernilai positif, sehingga hubungan kedua variabel tersebut bersifat searah. Sehingga dapat diartikan bahwa apabila pemanfaatan media sosial semakin ditingkatkan maka pemenuhan kebutuhan informasi ketenagakerjaan juga akan meningkat. Hal ini sejalan dengan penelitian yang dilakukan oleh Trinanda dan Sulihyantoro (2019), dari penelitian yang dilakukan dengan menggunakan perhitungan Rank Spearman bahwa terdapat hubungan yang positif dan sangat kuat antara penggunaan media sosial dengan pemenuhan kebutuhan informasi mengenai rekomendasi film box office di kalangan followers akun Twitter @WatchmenID.

\section{PENUTUP}

Dari hasil uji hipotesis diperoleh bahwa hubungan variabel pemanfaatan media sosial dengan pemenuhan kebutuhan informasi ketenagakerjaan sangat erat. Hubungan tersebut bernilai signifikan dan positif yang menunjukkan bahwa apabila pemanfaatan media sosial semakin ditingkatkan maka pemenuhan kebutuhan informasi ketenagakerjaan juga akan meningkat. Hasil perhitungan juga menunjukkan bahwa nilai signifikansi (sig.2-tailed) $=0,000$. Nilai tersebut lebih kecil dari 0,05 yang menunjukkan adanya hubungan yang signifikan sehingga Hoditolak dan Ha 
diterima. Jadi dapat disimpulkan bahwa penelitian ini menunjukkan adanya hubungan siginfikan yang sangat kuat dan searah antara variabel pemanfaatan media sosial dengan pemenuhan kebutuhan informasi ketenagakerjaan di kalangan angkatan kerja muda pada masa pandemi Covid19.

Kajian ini tidak lepa dari keterbatasan, diantaranya adalah responden yang dilibatkan dalam penelitian belummenjangkau seluruh populasi, sehingga kurang merepresentasikan hasil yang dapat digeneralisasi secara utuh. Penggunaan instrumen kuesioner dapat mengandung kelemahanjika direspon kurang cermat atau kurang sungguh-sungguh oleh responden. Kajian ini hanya melibatkan satu variabel yang berhubungan dengan pemenuhan kebutuhan informasi, sehingga penelitian yang dilakukan belum komprehensif. Oleh karena itu, kajian mengenai pemanfaatan media dalam rangka memenuhi kebutuhan informasi ketenagakerjaan harus dilakukan secara berkelanjutan. Hal tersebut menjadi penting untuk dilakukan karena ditengah pandemi Covid-19 yang mengancam kehidupan perekonomian, penggunaan media secara negatif masih banyak terjadi di Indonesia. Informasi yang berisi berita bohong dan penipuan yang terkait dengan bidang ketenagakerjaan seringkali didapatkan melalui media sosial. Melalui penelitian yang berkelanjutan, diharapkan dapat memperoleh faktor-faktor yang lain yang turut mendukung pemenuhan kebutuhan informasi terkait ketenagakerjaan. Berdasarkan hasil tersebut diharapkan informasi ketenagakerjaan yang disebarkan melalui media sosial dapat terus terjaga nilai kebenaran dan kebaruannya, sehingga khalayak dapat memanfaatkan informasi dengan sebaik-baiknya dan pembangunan ketenagakerjaan di Indonesia dapat kembali bangkit setelah dihantam pandemi.

\section{DAFTAR PUSTAKA}

APJII. (2020). Laporan Survei Internet APJII 2019-2020-Q2. https://apjii.or.id/survei

Ashrianto, P. D., \& Yustitia, S. (2020). The Use of Social Media in Searching for Information about Papua. Jurnal The Messenger, 12(2), 122. https://doi.org/10.26623/themessenger.v12i2.1939

Bagus P, A., N, A., Fathin, A., Ranggajati, A., W, A. D., S, D. R., Wijayanti, R., \& W., Y. M. (2020). Melindungi Pekerja Rentan di Masa (dan Pasca) Pandemi Covid-19. Journal of Chemical Information and Modeling, 53(9), 1689-1699.

BPS. (2021a). Booklet Sakernas : Survei Angkatan Kerja Nasional Fungsi Statistik Ketenagakerjaan. Badan Pusat Statistik.

BPS. (2021b). Keadaan Angkatan Kerja Di Indonesia Februari 2021. Badan Pusat Statistik.

Budiastuti, D., \& Bandur, A. (2020). Validitas dan Reliabilitas Penelitian. https://doi.org/10.31219/osf.io/tr4m7

Fatmawati, E. (2015). Kebutuhan Informasi Pemustaka Dalam Teori Dan Praktek. Info Persada, 13(1), 1-12.

Harahap, M. A., \& Adeni, S. (2020). Tren penggunaan media sosial selama pandemi di indonesia. Jurnal Professional FIS UNIVED, 7(2), 13-23.

Hossain, M. A. (2019). Effects of uses and gratifications on social media use. PSU Research Review, 3(1), 16-28. https://doi.org/10.1108/prr-07-2018-0023

Husnul, N. R. I., Prasetya, E. R., Sadewa, P., Ajimat, \& Purnomo, L. I. (2019). STATISTIK DESKRIPTIF (Issue 1). https://doi.org/10.1007/978-3-662-48986-4_2900

Karunia H, H., Ashri, N., \& Irwansyah, I. (2021). Fenomena Penggunaan Media Sosial : Studi Pada Teori Uses and Gratification. Jurnal Teknologi Dan Sistem Informasi Bisnis, 3(1), 92-104. https://doi.org/10.47233/jteksis.v3i1.187

Muttaqin, M. (2019). Internet Usage Behavior of the ICT Young Workforce in the Border Region. Journal Pekommas, 4(1), 11. https://doi.org/10.30818/jpkm.2019.2040102

Nadella, N., \& Rahadi, D. R. (2020). Pengembangan Kompetensi Di Masa Pandemi COVID 19. INOBIS: Jurnal Inovasi Bisnis Dan Manajemen Indonesia, 4(1), $72-83$. https://doi.org/10.31842/jurnalinobis.v4i1.167

Nasution, M. (2020). Ketenagakerjaan Indonesia : Menghadapi Pandemi, Menjelang Bonus Demografi. Pusat Kajian Anggaran Badan Keahlian DPR RI, 1-14.

Ngadi, N., Meliana, R., \& Purba, Y. A. (2020). Dampak Pandemi Covid-19 Terhadap Phk Dan Pendapatan Pekerja Di Indonesia (the Impact of Covid-19 on Worker Layoffs and Income in Indonesia). Jurnal 
Kependudukan Indonesia, 2902, 43-48. http://ejurnal.kependudukan.lipi.go.id/index.php/jki

Nia, L., \& Loisa, R. (2019). Pengaruh Penggunaan New Media Terhadap Pemenuhan Kebutuhan (Studi Tentang Media Sosial Facebook Dalam Pemenuhan Informasi di Kalangan Ibu Rumah Tangga). Prologia, 3(2), 489. https://doi.org/10.24912/pr.v3i2.6393

Novianti, E., Ruchiyat Nugraha, A., Komalasari, L., Komariah, K., \& Rejeki, S. (2020). Pemanfaatan Media Sosial Dalam Penyebaran Informasi Program Pemerintah (Studi Kasus Sekretariat Daerah Kabupaten Pangandaran). AL MUNIR : Jurnal Komunikasi Dan Penyiaran Islam, 11(1), 48-59. https://ejournal.uinib.ac.id/jurnal/index.php/almunir/article/view/1499/1120

Nurul, F., \& Zalmi, H. (2017). Pemenuhan kebutuhan informasi dalam perkumpulan kaum suku Jambak Dt . Maruhun Basa Kabupaten Agam. 2(2), 219-230. https://doi.org/10.15548/shaut.v9i2.120

Ozili, P. K., \& Arun, T. (2020). Spillover of COVID-19: Impact on the Global Economy. SSRN Electronic Journal. https://doi.org/10.2139/ssrn.3562570

Putra, Y. S. (2017). Theoritical Review : Teori Perbedaan Generasi. Among Makarti, 9(2), 123-134. https://doi.org/10.52353/ama.v9i2.142

Ratya, M. P. (2018). Lewat Medsos, Kemnaker Perluas Informasi Ketenagakerjaan. https://news.detik.com/berita/d-3988669/lewat-medsos-kemnaker-perluas-informasi-ketenagakerjaan

Rohmah, N. N. (2020). Media Sosial Sebagai Media Alternatif Manfaat dan Pemuas Kebutuhan Informasi Masa Pandemik Global Covid 19 (Kajian Analisis Teori Uses And Gratification). Al-I'lam: Jurnal Komunikasi Dan Penyiaran Islam, 4(1), 1-16. https://journal.ummat.ac.id/index.php/jail/article/view/2957/1905

Rosini, R., \& Nurningsih, S. (2018). Pemanfaatan media sosial untuk pencarian dan komunikasi informasi kesehatan. Berkala Ilmu Perpustakaan Dan Informasi, 14(2), 226. https://doi.org/10.22146/bip.33844

Saleh, G., \& Pitriani, R. (2018). Pengaruh Media Sosial Instagram dan WhatsApp Terhadap Pembentukan Budaya “Alone Together." Jurnal Komunikasi, 10(2), 103-114.

Suharto. (2015). Hubungan Daya Tanggap Terhadap Loyalitas Pelanggan menggunakan rank spearman. $51-63$.

Suparmo, L. (2017). Uses and Gratifications Theory dalam Media Sosial WA (WhatsApp). Communicology: Jurnal Ilmu Komunikasi, 5(2), 27-37. https://doi.org/10.21009/communicology.062.02

Whiting, A., \& Williams, D. (2013). Why people use social media: a uses and gratifications approach. Qualitative Market Research: An International Journal, 16(4), 362-369. https://doi.org/10.1108/QMR06-2013-0041 
JURNAL STUDI KOMUNIKASI DAN MEDIA

Vol. 25 No. 2 Desember 2021 Hal : 203 - 222 